Teosofia: Indonesian Journal of Islamic Mysticism, Volume 7, Number 1, 2018

\title{
THE CONCEPT OF TRANSCENDENTAL LOVE IN THE TAFSĪR AL-QURĀN AL-AZ̄īM BY AT-TUSTURIY
}

\author{
Hakki Akmal Labib \\ STAI Al Muhammad Cepu Blora \\ hakkiakmal@ymail.com
}

\begin{abstract}
The concept of h ubb is closely related to daily life. Anyone must have love. Whether it's love from biological aspect, social aspect, or theological aspect. This is one of the reasons why researchers choose the term $h u b b$. And the other reasons are, first, the word $h u b b$ is one of the key words in al-Qurā $n$ that describes the concept of deed, whether it is the concept of worship, as well as the social concept beloved by God and it is important to be known as the sustainer of everyday life. Secondly, the translation of al-Qurā n gives only the earliest description of the meaning of the word h ubb only to the extent of the meaning of love, thus requiring a deeper explanation in order to know its meaning comprehensively. So, this study will discuss about the concept of h ubb according Sahl bin 'Abdulla $h$ at-Tusturī in Tafs̄̄ $r$ al-Qurā $n$ al-Az $\bar{l} \mathrm{~m}$. He was known by a mutas awwī fand mufassī $r$.
\end{abstract}

Keywords: concept, Hubb, at-Tusturī , Tafsī r al-Qurā n al-Az ī m

\section{A. Introduction}

$\mathrm{I}$

$\mathrm{n}$ the Qur'an, themes such as the problem of mystical experiences such as khauf, raja ', mahabbah and others are often understood to be limited to textual information. His thinking was shackled by the description of the world. The process of negative transformation of the understanding of the Koran is actually getting support from interpretive works that exist in the literature of tafsīr. ${ }^{1}$

One interesting theme related to the symbolic theme is the verses of the Koran which talk about the term $h u b b$. The concept of $h u b b$ which in Islamic studies is also known as mahabbah is very popular among the Islamic community, and is very interesting. Based on the results of investigations by researchers in the book Mu'jam al-Mufahrās lī Alfāz al-Qurān by Muhammad

\footnotetext{
${ }^{1}$ Fazlur Rahman. Tema Pokok Al-Qur'ān, Trans. Anas Mahyudin, (Bandung, Pustaka, 2 ${ }^{\text {nd }}$ print, 1996),
} ix. 
Fu'ād Abd al-Baqī lafaz hub with various forms, there are 83 verses in the Qur'an. ${ }^{2}$ Although in the Qur'an there are so many verses using this editorial, it turns out that people often return the definition of the concept of $h u b b$ to the opinions of the scholars of Sufism (mutașawwifin) using the editorial mahabbah.

According to In'amuzzahidin, the word mahabbah has several meanings, including: clean white (al-safa wa al-bayad $)^{3}$, tall and clear (al-'uluww wa al-zuhur) ${ }^{4}$, permanent and firm (alluzum wa al-sabat), plant seeds (al-habb) and others.

Mahabbah is a great feeling where the person who loves gives all the nobleness of his soul to the beloved. Mahabbah implies strength and stability to be consistent with what he loves, and always think of what he loves. Al-Junaid states that a person who is struck by love will be filled with memories of his lover, so that no one is left behind, except memories of his lover, even he forgets his own nature. Even willing to sacrifice whatever he has for the loved one. All that is done with not the slightest feeling of weight or pressure, but solely just pleasure. ${ }^{5}$

Mahabbah according to al-Gazālī is an instinctive inclination to something pleasant. ${ }^{6}$ The emergence of feelings of love or mahabbah is due to a strong urge on a person to be close to his beloved lover. This urge to be close is caused by an attachment or feeling like something that gives rise to pleasure. The feelings of love for something cause love. ${ }^{7}$

When referring to al-Munawwir's dictionary, the word hubb means love, like. But to trace a word's meaning in the Qur'an it is not enough to refer to the dictionary and only look at the Qur'an and its translation. ${ }^{8}$

So, in this study, researchers will discuss about the concept of hubb according to Sahl bin 'Abdullāh at-Tusturī in Tafsīr al-Qurān al-Azīm. He was one of the figures considered to be the ulama' who first interpreted the Qur'an from the Sufi circles. ${ }^{9}$

\section{B. Sahl bin 'Abdullāh at-Tusturī and Tafsīr al-Qurān al-Aīim}

${ }^{2}$ Muhammad Fu'ād Abd al-Baqī, Mu'jām al-Mufahrās $\hbar$ Al Alfāz al-Qurān, (Kairo: Dār al-Kutub Mishriyyah, 2004), 191-193.

${ }^{3}$ Because the word is used by Arabs, to show the clean and white of a tooth. See In'amuzzahidin Masyhudi, From Wali Sufi GIla, (Semarang: Syifa Press, 2007), 35.

${ }^{4}$ Among the meanings of the word is a wave of water. Ibid.

${ }^{5}$ Moenir Nahrowi Tohir, Menjelajahi Eksistensi Tasawuf, (Jakarta: As-salam Sejahtera, 2012), 101-102.

${ }^{6}$ Imam Al-Ghazali, Ajaran Bahasa Imam Al-Ghazali, Terj. Yudhi AW., (Yogyakarta: Cakrawala, 2011), 139.

${ }^{7}$ Imam al-Ghazali, Samudera Ma'rifat, Terj. Tim Creative Kauka, (Yogyakarta: 2008), 262-263.

8 Ahmad Warson Munawir, Kamus al-Munawwir Arab-Indonesia Terlengkap, (Surabaya: Pustaka Progressif, 1997), 229. vol. II, 281.

${ }^{9}$ Muhammad Husain aż-Żahabī, at-Tafs̄̄r wa al-Mufassinūn, (Mesir: Dār al-Kutub al-Ḥadīsah, 1961),

Teosofia: Indonesian Journal of Islamic Mysticism, Volume 7, Number 1, 2019 


\section{Biography and Educational Background of at-Tustur}

Sahl ibn 'Abdullāh at-Tusturī with the full name Abū Muḥammad Sahl ibn' Abdullāh ibn Yusnus ibn Īāsā ibn 'Abdullāh ibn Rafî' at-Tusturī. He is also commonly called by the nickname (chew) Abū Muhammad or his family name (nisbah) at-Tusturī. Sahl at-Tusturī is a one of the Sufi scholars and mutakalliminn (theologians) in the science of riyaḍah (soul training), ikhlāṣ, and wirā' $\mathrm{i}$ experts. ${ }^{10}$

Sahl at-Tusturi was born in Tustar (said in Persian to be Shushtar), one of the areas in Khūzistān, Ahwāz, west of Iran in 200 H. / 815 AD and died in Bașrah in 283 H. / 896 CE. ${ }^{11}$ He lived in the 3rd century, namely the century of the development of the scientific world and gave birth to many great scholars. ${ }^{12}$

At-Tusturi's interest in the ideas and practices of the practice of Sufism began with the ritual of Sufism carried out by his uncle, Muhammad bin Sawwār. At the age of three, Sahl atTusturi was accustomed to getting up in the middle of the night and witnessing how his uncle performed night prayers. However, the uncle always told him to go back to sleep. When he was right, one day before the uncle intended to introduce Sufism to him and asked, "Can you remember the God who created you?" Sahl at-Tusturī replied, "How can I remember Him?" The uncle also gave instructions "Say three times in your heart without moving your tongue when you go to sleep at night, 'Allah is with me, Allah is watching me, Allah is my witness."' Sahl at-Tusturi obeyed the command and carried it out for ten days. After that time the uncle then multiplied the number to ten, twenty-one times, and continued to increase for the following nights. ${ }^{13}$

Sahl at-Tusturī marries a wife and has a child. He looks happy in his married life, even his wife also participates in the same zuhud life. This simple lifestyle, which directs all his needs to God is also a foundation for educating his family and children. ${ }^{14}$ The great name of Sahl atTusturī as a Sufi has led Muslims to regard him as a wali, whose tombs have been visited by people for centuries.

${ }^{10}$ Zain ad-Dīn Muhammad 'Abd ar-Ra'ūf al-Manāwī, al-Kawākib ad-Durriyyah fi Tarājim as-Sādat așȘūfiyyah, Vol. I, (Beirūt: Dār Șadir, 2004), 634; Muḥammad Sahl bin 'Abdullāh at-Tusturī, Tafš̀r al-Qurān al-Aẓìm, 67 ;

${ }^{10}$ Muhammad Sahl bin 'Abdullāh at-Tusturī, Tafs̄ir al-Qurān al-Aẓ̄̄m, 67; Muhammad Husain aż-Żahabī, at-Tafsìr wa al-Mufassin̄̄n, vol. II, 281; Zain ad-Dīn Muhammad 'Abd ar-Ra'ūf al-Manāwī, al-Kawākib adDurriyyah fi Tarājim as-Sādat aș-Ṣüfiyyah, Vol. I, 647.

${ }^{11}$ Muhammad Sahl bin 'Abdullāh at-Tusturī, Tafs̄̄r al-Qurān al-Aẓīm, 67; Muhammad Husain aż-Żahabī, at-Tafsìr wa al-Mufassinūn, vol. II, 281.

${ }^{12}$ Man̄̄’ Abd al-Halīm Maḥmūd, Manāhij al-Mufassin̄n, (Kairo: Dār al-Kutub al-Miṣrī, 2000), 29.

${ }^{13}$ Muhammad Sahl bin 'Abdullāh at-Tusturī, Tafs̄ìr al-Qữàn al-Aẓīm, 67.

${ }^{14}$ Gerhard Böwering, The Mystical Vision of Existence in Classical Islam; The Qur'ānic Hermeneutics of Sufí at-Tustan̄ (d. 283/896), 44. 
Sahl at-Tusturi's formal education starts at a traditional school. At the age of six years Sahl at-Tusturī had memorized the Qur'an and he studied its contents at the age of seven. ${ }^{15}$ Sahl atTusturī also studied the scholars in the Bașrah, especially to Hamzah al-'Abbādān̄i. ${ }^{16}$

Apart from his uncle Muhammad bin Sawwār and Ḥamzah al-'Abbādānī who had significant influence on the formation of Sahl at-Tusturī's intellect and spirituality, another Sufi figure who made a major contribution to Sahl at-Tusturī was $\dot{Z} \bar{u}$ an-Nūn al-Mișrī. He met Żū an-Nūn al-Mișrī during the Hajj in Mecca. ${ }^{17}$ The influence of this last character was very important, especially in teaching the resignation to God. ${ }^{18}$

\section{Tafsīr al-Qurān al-Aẓīm}

In general it can be said that Tafsìr al-Qurān al-Ażìm illustrates the characteristic of Sahl at-Tusturī's thought work which combines traditional interpretative styles and rational reasoning. The style of traditional interpretation can be seen through interpretations that are based on the opinions of Sufi figures who lived in earlier periods, or also on the interpretation of verses based on a literal explanation of their meaning. While reasoning is rationally manifested in the process of judgment by using analogies, where the expressions that represent the literal explanation are compared with the construct of mystical thought which marks moral significance as its symbolic description. Even unique, the symbolic interpretation method used by Sahl at-Tusturī also has a character of thought that includes the aspect of making an argument in naqli for the basis of drawing the analogy. Such procedures are taken either through affirmation in the form of al-Qur'an statements contained in other surahs, or by using statements derived from the hadith. ${ }^{19}$

The main structure of the content of this interpretation can be divided into two parts, namely: introduction and content of interpretation. The introductory part consists of two subchapters, namely muqaddimah and sub-chapters regarding the characteristics of the search for understanding of the Qur'an. The muqaddimah section consists of two introductory pages about the general concept of the Qur'an. Among the things emphasized by the importance of Sahl atTusturi in the introduction to this introduction is the doctrine that al-Qurān is the mother book whose meanings of each sentence can be divided into four levels of meaning: zāhir, bātin, hadd,

\footnotetext{
${ }^{15}$ Abū Muhammad bin As'ad bin 'Al̄̄ bin Sulaimān al-Yāfi'ī al-Yaman̄̄ al-Makkī, Mirāt al-Jinān wa 'Ibrah al-Yaquān, Vol. II, 149; Mani’ Abd al-Halīm Maḥmūd, Manāhij al-Mufassinīn, 30.

${ }^{16}$ Zain ad-Dīn Muhammad 'Abd ar-Ra'ūf al-Manāwī, al-Kawākib ad-Durriyyah fî Tarājim as-Sādat așȘūfiyyah, Juz. I, 635; Gerhard Böwering, The Mystical Vision of Existence in Classical Islam; The Qur'ānic Hermeneutics of Sufi at-Tustañ (d. 283/896), 48.

${ }^{17}$ Abū al-'Abbās Syams ad-Dīn Aḥmad bin As‘ad bin Mụ̣ammad bin Abī Bakr bin Khallikān, Wafiyāt al-A 'yān wa Anbā' u Anbā'i az-Zamān, Vol. II, 429; Muhammad Sahl bin 'Abdullāh at-Tusturī, Tafs̄̄r al-Qurān alAẓ̄im, 67.

${ }^{18}$ Gerhard Böwering, The Mystical Vision of Existence in Classical Islam; The Qur'ānic Hermeneutics of Sufi at-Tustañ (d. 283/896), 51.

${ }^{19}$ Ibid., 131.
}

Teosofia: Indonesian Journal of Islamic Mysticism, Volume 7, Number 1, 2019 
and matla'. As a consequence, Sahl at-Tusturī also classifies the differences in groups of people in reading the Qur'an. In the sub-chapter which confirms the general characteristics of the search for understanding of the Qur'an, Sahl at-Tusturi begins his explanation by describing the status of the Qur'an as tanzīl, God's revelation revealed to Muhammad's heart. The character of alQurān as tanzīl and in relation to its status as a master book that contains many meanings is the main basis of the principle of interpretation of Sahl at-Tusturi which confirms how the interpretation of al-Qurān should be carried out. The introduction written is a description of how he outlines the basic framework of his interpretation of the Qur'an. ${ }^{20}$

The contents of the Sahl at-Tusturi interpretation of the verses of the Koran in the book of exegesis begins by placing a subchapter on the meaning of basmalah. The next description is the serial interpretation of all 114 surahs contained in the Qur'an. However, Sahl at-Tusturi chose only certain verses from each surah to be interpreted according to indications which he was able to capture through his capacity as a Sufi. There is no specific standard on how many verses he takes to be interpreted in each surah. There are at least three verses from each short surah that are given an interpretation by Sahl at-Tusturī. The number of verses interpreted can multiply when he discusses lengthy chapters. In Sahl at-Tusturī's view, several suras al-Qurān occupy important positions, especially surah al-Fātihah and al-Ikhlās, even though the number of verses in the suras is only seven and three verses only. ${ }^{21}$

\section{The Concept of Hubb According to at-Tusturī in the Tafsīr al-Qurān al-Ažìm}

1. Definition and Nature of Hubb According to At-Tusturī in the Tafsìr al-Qurān al-Aìm.

According to at-Tusturī, $h u b b$ is cohesion in obedience and aversion to differences. ${ }^{22}$ Another meaning of hubb is anything that does not make the loved one not love. ${ }^{23}$ The very deep meaning of hubb is also conveyed by 'Abd al-Halīm Maḥmūd in the book of al-'Ārif billāh Sahl bin' Abdullāh at-Tusturī Hayātuhu wa Ārāuhu, that hubb according to at-Tusturī is that you love everything that your loved one loves and hates everything he/she hates. ${ }^{24}$

At-Tusturī illustrates ubub with a fire that can burn everything. As at-Tusturī explains in the interpretation of Q.S. al-Humazah (104) verse 6 that there are four types of fire, namely: Dar al-Syahwah; Nār asy-Syaqāwah; Nār al-Qațī'ah; and Nar al-Maḥabbah. At-Tusturī explained that Nar-ash-Shahwah burned the power or ability of obedience to Allah, Nar-ash-

${ }^{20}$ Ibid, $128-130$

21 Ibid.

${ }^{22}$ See his interpretation on Q.S. al-Baqarah (2) ayat 165. Muhammad Sahl bin 'Abdullāh at-Tusturī, Tafsīr al-Qurān al-Aẓ̄m 118.

23 Ibid., 128.

${ }^{24}$ Abd al-Ḥalīm Maḥmūd, al- 'Ārif billāh Sahl bin 'Abdullāh at-Tustuñ Hayātuhu wa Ārāuhu, (Kairo: Dār al-Ma'ārif, 1994), 123. 
Shafiq burned monotheism, Nar-al-Qați’' ah burned hearts and Nar al-Mahabbah burned all the fires. $^{25}$

From this explanation, the researcher saw that the submission of the heart and obedience of all limbs to the command of sharia 'and avoiding its prohibition is the highest position in the concept of hhubb at-Tustur'. In it there is the spirit of hauf and raja ', which is very relevant to shari'ah, this is different from some Sufi scholars who say that" I worship Allah not because I want heaven and not because of fear of hell ". According to at-Tusturī, the statement is contrary to Q.S. al-Isrā '(17) verse 57 which states:

$$
\text { وَيَزْجُونَ رَخْمَتَهُ وَيَخافُونَ عَذَابَهُ }
$$

Meaning: they expect His mercy and are afraid of His punishment ...

According to at-Tusturi, the above verse in the meaning of hirāhir means "the mercy of Allah in the form of heaven". And in its bātin meaning the word rahmat means "ma'rifat to Allah". According to at-Tusturī', 'auf and rajā 'both must exist in every human being. If both are balanced, then the situation is perfect, if one of the two is superior, then it becomes invalid. ${ }^{26}$

At-Tusturī in the explanation of Q.S. al-Isrā '(17) verse 57 above also quotes a narration stating that:

لو وزن رجاء المؤمن وخوفه لأعتدلا

Meaning: If the 'believers and rajā' of the believers are weighed, surely they will not be biased. $^{27}$

And also contrary to the word of Allah. who talks about His lovers in Q.S. as-Sajdah (32) verse 16 which states:

$$
\text { يَذْعُونَ رَبَّهُمْ خَوْفافَ وَطَمًَا }
$$

Meaning: .. they pray to their Lord with fear and hope ...

According to at-Tusturī, the above verse shows that His lovers are always afraid to leave their Lord and hope to be able to meet their Lord. ${ }^{28}$

Speaking of hauf and raja 'in relation to the concept of hubb, according to at-Tustur hauf and rajā' is like two wings for believers and $h u b b$ grows from good raj $\bar{a}$ '(ar-rajā al-ḥasan). According to al-Tustarī, hauf fosters love, unbelievers claim hubb (love) to Allah but He does

${ }^{25}$ Muḥammad Sahl bin 'Abdullāh at-Tusturī, Tafs̄ì al-Qữàn al-Aẓīm, 329.

${ }^{26}$ Ibid., 188 .

${ }^{27}$ This is also mentioned in Syu'b al-Īmān by Aḥmad bin al-Ḥusain bin 'Ālī bin Mūsā al-Kharāsanī, Abū Bakr al-Baihaqī. See Aḥmad bin al-Ḥusain bin 'Ālī bin Mūsā al-Kharāsan̄̄, Abū Bakr al-Baihaq̄i, Syu’b al-Īmmān, Vol. II, (Riyad: Maktabah ar-Rusy li an-Nasyr wa at-Tauz’’’, 1423 H./2003 M.), 327.

${ }^{28}$ Muḥammad Sahl bin 'Abdullāh at-Tusturī, Tafsìr al-Qurān al-Aẓ̄̄m, 221.

Teosofia: Indonesian Journal of Islamic Mysticism, Volume 7, Number 1, 2019 
not give faith, whereas those believers hubb (love) to Allah which cause hauf (fear) to Allah and Allah bestows faith in him. As at-Tustur's interpretation in Q.S. al-Baqarah (2) verse 165.

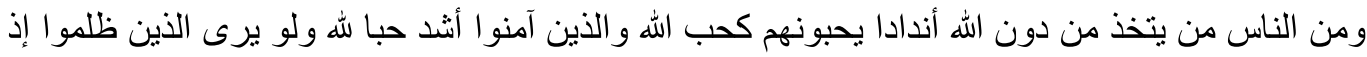

$$
\begin{aligned}
& \text { (يرون العذاب أن القوة لله جميعا وأن الله شديد العذاب (170 }
\end{aligned}
$$

Meaning: And among humans are those who worship god other than Allah as a rival, whom they love as they love God. As for those who have great faith, their love for Allah. If those who do wrong see, when they see the punishment (on the Day of Resurrection), that the power belongs to Allah, and that Allah is very severe in His punishment (surely they regret it).

In Q.S. al-Baqarah (2) verse 165, at-Tusturī explains how the love of unbelievers to alAndād equals their love of Allah. This is what causes kufr and their justification to al-Andād which makes God attribute them to the category of those who disbelieve openly. As for those who justify their faith in Allah, Allah attributes them to the category of believers whom He loves. ${ }^{29}$

Regarding al-Andad's own definition, at-Tusturī has explained the interpretation of QS. alBaqarah (2) verse 22.

In the verse fragment

فَلَا تَجْعَلُوا الََِّهِ أَنَدَدادًا

Meaning: ... Do not make contradictions for Allah ...

According to at-Tusturī, the word andād which means "contradictions," is interpreted as andād (أضداد) which means "that which contradicts". The meaning of the word andād according to at-Tusturī is the nafs ammārah which always plunges people into evil deeds, which only prioritizes personal desires and interests without heeding the guidance of Allah. ${ }^{30}$ So the purpose is not only statues, demons or souls, but also the nafs ammärah which is often made by God by humans. Because humans always associate their Lord with always being a servant. From this it can be seen that, according to at-Tusturi the greater counterpart is the nafs ammärah bi as-sü' (lust that always commands evil) even though the verse does not in the end refer to ammārah bi as-sü' nafs, but everything that is contrary to Allah.

In the statement "Gentiles (love) to Allah", it seems that in the understanding of at-Tusturi unbelievers think they love God but they do not follow the path that can convey to Him, namely $i t b \bar{a}$ '(following the Apostle) so that they don't get what they say which is the true $h\} u b b$. Because itbā 'is a requirement in hubb, as the word of Allah Q.S. Āli Imrān (3) verse 31

$$
\text { قل إن كنتم تحبون الله فاتبعوني يحبيكم الله ويغفر لكم ذنوبكم والله غفور رحيم }
$$

\footnotetext{
${ }^{29}$ Muḥammad Sahl bin 'Abdullāh at-Tusturī, Tafs̄ir al-Qurān al-Aẓ̄̄m, 118.

30 Ibid., 90 .
} 
Meaning: Say (Muhammad): "If you love Allah, follow me, surely Allah loves you and forgives your sins." Allah is Forgiving, Most Merciful.

The purpose of this verse according to Sahl at-Tusturī is for us to get $h u b b$, then we must follow the Prophet Muhammad and because we follow the Prophet Muhammad. we get a reply from Allah in the form of hubb. And hubb is the height of glory. ${ }^{31}$

In his interpretation, Sahl al-Tustari explained the question addressed to him;

What will God do for His servants when I love Him? Sahl at-Tusturī replied: "Allah will inspire him istighfār when he gets shortages and give him thanks when he gets pleasure".

The statement at-Tusturī is very precise, because in fact Allah's help will be given to His servant when he loves Him by inspiring him to seek forgiveness and gratitude. Istighfär shows the complaint of the soul in the sight of Allah as well as the love of a servant to His Lord. The gratitude leads to increased enjoyment from God to His servants and shows the guardianship of the heart that is always struggling with its creator as well as acknowledgment of poverty for the favors of the favors who ultimately require gratitude to Him. ${ }^{32}$

In the explanation of Q.S. al-Baqarah (2) verse 165, at-Tusturi quotes the saga,

That Allah Most High ask Mūsā As: "Have I bestowed upon you the love that comes from Me?", Mūsā answered "No O my Lord", so God answered: "Because you only expect things that are secret from me O Moses, know that I come down to you with full of care, so don't forget to remember me all the time, make it your goal to remember me, actually that is your path to me."

And one form of remembering Allah is to always say Istighfār and thank God to Allah.

In the QS section Tâaha (20) verse 39.

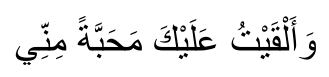

Meaning: I have bestowed upon you the love that comes from Me.

In the above verse, at-Tusturī interprets that Allah has revealed to the Prophet Mūsā the inheritance of knowledge before giving to charity. So from here at-Tusturī said that essentially all human beings have inherited hubb from Allah placed in the hearts of His servants. Because the heart can affect actions and thoughts. As humans find in their soul happy feelings without knowing the cause and feeling sad without knowing the cause.

In the explanation above, it can be understood that the love of a servant to his Lord is a condition that has been obtained and felt, but difficult to express, so to present " hubb "it is necessary to think to him. As at-Tustur's interpretation of the QS section. al-Baqarah (2) verse 165 which reads;

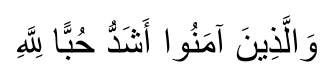

\footnotetext{
${ }^{31}$ Ibid., 166.

32 Ibid., 118.
}

Teosofia: Indonesian Journal of Islamic Mysticism, Volume 7, Number 1, 2019 
Sahl at-Tusturī interpreted "that those who believe have great love for Allah", that those who love God are caused by their ma'rifat and some causes of a believer can arrive at the presence of Allah in the form of always thinking to Him. From here Sahl at-Tusturi says that $h u b b$ is the nature of gift from God absolutely. And this thought to God must be done in a lonely (clandestine) and crowded (openly) at the same time accompanied by obedience to Allah.

From the above explanation, it can be understood that the concept of hubb is the harmony of the heart with Allah, consistent in its circumstances, following His Prophet, always dhikr and feel the sweetness of appearing with Him.

2. Characteristics of hubb According to At-Tusturī in the Tafsīr al-Qurān al-Adhìm.

Regarding the characteristics of $\mathrm{h} h u b b$ according to at-Tusturiy, the researcher takes his interpretation on Q.S. Āli Imrān (3) verse 92.

Meaning: You will not get virtue, before you invest some of the treasure that you love. And whatever you want, about that, truly, God knows.

The purpose of this verse according to Sahl at-Tusturi is that we will not arrive at piety until we are able to ignite our passions by spending part of what we love. Infaq is also not only because of lust, but only expects what Allah is pleased with.

In the explanation of this verse Sahl at-Tusturī also quotes saga,

That the Prophet 'İsā As. one day walking and meeting with three groups of people. The first group looks thin and changes color. Then the Prophet 'İsā As. ask: "What happened to you?", they answered: "Fear our Creator and remember the torments that will befall us for our sinful conduct", so the Prophet said 'Assa: -His". Then the Prophet 'Īsā As walked again. and met the second group, they looked very thin. Then the Prophet 'Īsā As. asking: "What happened to you?", They answered: "A deep longing for our Lord", then said the Prophet .: àsā As: "The right of Allah to give you what you expect". Then the Prophet 'Îsā As walked again. and met the third group who looked very thin and pale in the face. Then the Prophet 'Īsā As. asking: "What happened to you?", They answered: "Love", then said the Prophet 'āsā As .:" You are a category of people who are close to Allah. Whoever loves Allah. then he is close to Him, because people who love something, he/she rushed to it. ${ }^{33}$

Based on the saga above, Sahl at-Tusturi said that there are three levels. First; is the level of those who repent; second, is the level of those who yearn; and third, is the level of people who love. ${ }^{34}$

The saga above, shows how they try to preach all they can do, and reject everything that can take them away from Allah.

\footnotetext{
${ }^{33}$ Muhammad Sahl bin 'Abdullāh at-Tusturī, Tafs̄̄r al-Qurān al-Aẓīm, 124-125.

${ }^{34}$ Muḥammad Sahl bin 'Abdullāh at-Tusturī, Tafs̄̄r al-Qurān al-Aẓ̄m, 125.
} 
From this explanation it can be understood that according to at-Tusturi the main feature of hubb is to obey Allah by obeying all that He commands, because the lover is he who can stay away from His prohibitions.

And when a servant's love for Allah has made God's love for him, then what he will get is as Allah said in Q.S. al-Māidah (5) verse 54 which reads:

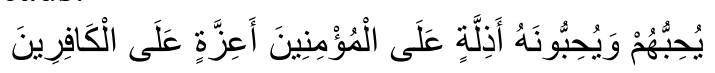

That is, if God already loves him then God will provide His protection and help to the servants who he loves to fight his enemies. Both enemies in the form of enemies who are zahir and enemies in the form of lust and lust. ${ }^{35}$

Therefore, Allah says Q.S. al-Nisa (4) verse 45 which reads:

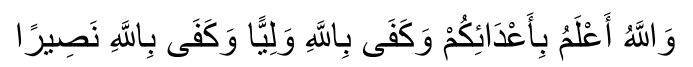

Meaning: And Allah knows better about your enemies. It is enough for God to be protective and enough for God to be a helper (for you).

In a history stated:

$$
\text { جبلت القلوب على حب من أحسن إليها وبغض من أساء إليها. }
$$

Meaning: The nature of the heart is to tend to love those who do good to them and hate those who do bad to them. ${ }^{36}$

At-Tusturi in explaining Q.S. al-Māidah (5) verse 54 says that the character of hubb to Allah is to love al-Qurān, the character of bhubb to al-Qurān is hubb to the Prophet Muhammad, and the character of bhubb to the Prophet Muhammad. is hubb to his sunna, ubub to sunnah is ubub to the afterlife, ubub to the afterlife is to hate the world and to hate the world is not to take it except for the afterlife. ${ }^{37}$ The words of al-Tusturi are sourced from the words of Ibn Mas'ūd "will not be asked by anyone among you except about al-Qurān, if he loves the Koran then he loves Allah and if he does not love al-Qurān then he does not love God". ${ }^{38}$

In an explanation of the characteristics of love for the Prophet Muhammad. is love for his sunna, can be seen in the at-Tustur's explanation when interpreting. ${ }^{39}$ The characteristic of love for the hereafter implies that someone should hate the world and the characteristic of hating the world is not to take it except for the provision of the hereafter.

In addition to the above characteristics, from the above explanation it can be understood that according to at-Tusturī, the characteristics of people who love their oral Allah will never

\footnotetext{
${ }^{35}$ Muḥammad Sahl bin 'Abdullāh at-Tusturī, Tafs̄̄r al-Qurān al-Aẓīm, 138.

${ }^{36}$ See Aḥmad bin al-Ḥusain bin 'Ālī bin Mūsā al-Kharāsanī, Abū Bakr al-Baihaqū, Syu’b al-Īmān, Juz.

${ }^{37}$ Abū Ṭālib al-Makkī Muhammad bin 'Ālī bin 'Ațiyyah, Qūt al-Quh̄ b fi Mu'amālat al-Mahbūb wa Waṣ $f$ Tan̄ al-Muñ dila Maqām at-Tauhīd, Juz II, (Kairo: Maktabah Dār at-Turāì, 1422 H./2001 M.), 1050.

38 Ibid.

${ }^{39}$ Muḥammad Sahl bin 'Abdullāh at-Tusturī, Tafs̄̄r al-Qurān al-Aẓ̄mm, 138.
} II, 38 .

Teosofia: Indonesian Journal of Islamic Mysticism, Volume 7, Number 1, 2019 
forget to mention His name (dhikr), always grateful for favor, always feeling with Him and busy carrying out orders His, and the greatest, is never to complain about his lover.

In a history mentioned, he treats people who are sick even though he himself looks (like) is sick. Then he was asked why you didn't treat yourself, he answered, "A lover's punch will not hurt his/her lover". ${ }^{40}$

3. The Conditions of hubb According to At-Tusturī in the Book of Tafsīr al-Qurān al-Aẓ̄m.

According to at-Tusturī, ma'rifat is something that is closely related to hubb. Therefore, in the view of at-Tustur hubb following ma'rifat, it is a condition in hubb, and a person will not love something unless he knows him (ma'rifat).

As explained by at-Tusturi in the interpretation of QS. al-Baqarah (2) verse 165 in the verse fragment

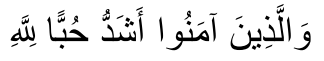

Sahl at-Tusturī interprets "that those who believe are of great love for Allah" due to their ma'rifat and some causes of a believer can arrive at the presence of Allah in the form of always thinking to Him. ${ }^{41}$

4. The practice ofhubb according to At-Tusturī in the Tafsīr al-Qurān al-Aīm.

At-Tusturī says in the Tafsīr al-Qurān al-Aẓìm, that:

There is no one like the Prophet Muhammad. in his khauf, hubb , longing, zuhud, blessing, resignation, and morals. ${ }^{42}$

From the narration of at-Tusturī above, shows that no human being can match the practice of the Prophet Muhammad. however, we do not necessarily say we should not practice. hhubb According to researchers, the reasons for citing the history carried out at-Tusturi show that the practice of $h u b b$ is sufficient to follow how the practice of hubb of the Prophet Muhammad SAW.

It should be noted that at-Tusturi bases his ideology and path of Sufism on seven principles, namely: holding to the Kitabulläh, following the Sunnah of the Prophet, eating the halal, not hurting (creatures), avoiding immorality, repentance and fulfilling rights. ${ }^{43}$ So from this it can be understood that the practice of "hubb at-Tustur "is also based on these seven principles.

In the practice of $h u b b$ in the form of holding to the Kitabullahh, it has been explained by at-Tusturi in the explanation of Q.S. al-Baqarah (2) verse 165.

\footnotetext{
Ma'rifah, t.th.), 347.

${ }^{41}$ Muhammad Sahl bin 'Abdullāh at-Tusturī, Tafs̄̄r al-Qurān al-Aẓīm, 118.

${ }^{42}$ Muḥammad Sahl bin 'Abdullāh at-Tusturī, Tafs̄̄r al-Qurān al-Aẓ̄ìm, 190.

${ }^{43}$ Muḥammad Sahl bin 'Abdullāh at-Tusturī, Tafs̄̄r al-Qưān al-Aẓ̄mm, 71.
}

40 Abū Hāmīid Muḥammad bin Muḥammad al-Gazālī, Ihyā̄' 'Ulūm ad-Dīn, Juz IV, (Beirut: Dār al- 


$$
\text { والقوة الله جميعاس وأن الله شنديد العذاب الندادا يحبونهم كحب الله والذين آمنوا أشد حبا له ولو يرى الذين ظلموا إذ يرون العذاب أن }
$$

Meaning: And among humans there are those who worship god other than Allah as a rival, whom they love as they love God. As for those who have great faith, their love for Allah. If those who do wrong see, when they see the punishment (on the Day of Judgment), that the power belongs to Allah, and that Allah is very severe in His punishment (surely they regret it).

In the explanation of this verse Sahl at-Tusturi writes the answer to the question addressed to him about the signs of mahabbah? Sahl at-Tusturi then replied that the signs of mahabbah are holding tightly (embracing) obedience and distancing themselves from personal needs. ${ }^{44}$ Sahl at-Tusturī also quoted the saga, that Allah Most High. ask Mūsā As: "Have I bestowed upon you the love that comes from Me?", Mūsā answered "No O my Lord", so God answered: "Because you only expect things that are secret from me O Moses, know that I come down to you with full of care, so don't forget to remember me all the time, make it your goal to remember me, actually that is your path to me. "45

In the practice of $h u b b$ in the form of following the Sunnah of the Prophet, it has been explained by at-Tustur in the explanation of Q.S. Āli Imrān (3) verse 31.

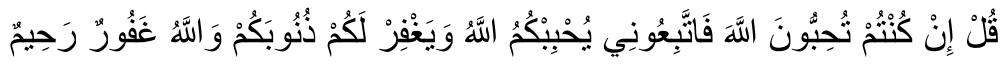

Meaning: Say (Muhammad): "If you love Allah, follow me, surely Allah loves you and forgives your sins." Allah is Forgiving, Most Merciful.

The purpose of this verse according to Sahl at-Tusturī is that in order for us to get a mahabbah, we must follow the Prophet Muhammad and because we follow the Prophet Muhammad. we get a reply from God in the form of mahabbah And this mahabbah is the height of glory. ${ }^{46}$

In practice $h u b b$ in the form of eating halal, has been explained by at-Tusturi in the QS explanation al-A'rāf (7) verse 31.

$$
\text { يا بني آدم خذوا زينتكم عند كل مسجد وكلو ا واشربو ا ولا تسرفو ا إنه لا يحب المسرفين }
$$

Meaning: O children of Adam! Wear your good clothes in every (enter) mosque, eat and drink, but don't overdo it. Truly, Allah does not like people who are overrated.

In the explanation of the verse, Sahl at-Tusturī says that there are five kinds of eating. The fifth is good, the sixth is bad; first; darürat (primary need); second; to perform worship; thirda; for strength; fourth; for proclamation; fifth; for sacrifice, and who wants to eat food mixed with

\footnotetext{
${ }^{44}$ Muhammad Sahl bin 'Abdullāh at-Tusturī, Tafs̄ir al-Qurān al-Aẓ̄̄m, 118.

${ }^{45}$ Ibid.

${ }^{46}$ Ibid., 166
}

Teosofia: Indonesian Journal of Islamic Mysticism, Volume 7, Number 1, 2019 
bad property. This verse teaches that even though this food command was ordered by God, he suggested that we restrain our appetite to eat a lot, because hunger will bring knowledge and wisdom. Because of this hunger God will bring His secrets to us. ${ }^{47}$

And in the QS section al-Hasyr (59) verse 9.

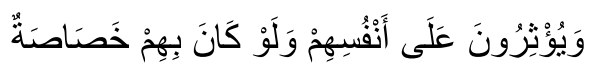

Meaning: And they have no desire in their hearts for what is given to them (Muhajirin); over themselves, even though they are strongly in need.

According to Sahl at-Tusturī, the intention is hunger (suffering) and poverty. The Arabs say: "A person will be devoted when he is in a state of poverty". Then they will get God's riḍa as a result of their desire, and the result that will be obtained is to feel the love of God. ${ }^{48}$

In the practice of $h u b b$ in the form of moving away from immorality, it has been explained by at-Tustur "in the explanation of Q.S. al-'Ādiyāt (100) verse 8.

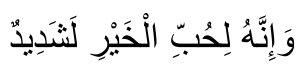

Meaning: and in fact his love for property is really excessive.

The meaning of $h u b b$ al-khair in the above verse is, according to Sahl at-Tusturī it can be classified into three types of actions: loving oneself (nafs), loving the world, and loving desires (haw $\bar{a}$ ). These three things are named khair because through the "treasure" the owners can get to know each other. ${ }^{49}$

In order for khair to have a positive meaning, then the real khair according to Sahl atTusturī, which is a khair that fulfills three things: does not depend on fellow beings, feels the need before God, and carries out his commands.

As Sahl at-Tusturi also provides interpretations for the two previous verses, relating to the basic character of humans who in addition to the stingers also renege to their Lord (Surah al'Adiyāt (100) verse 6) which Sahl explained with the equivalent of kafür with 3 main features : breaking promises, reneging on the truth, and delighting lust. Allah witnessed all these actions and all human things, both visible and confidential, so He also revealed the truth and the way of piety for humans. Moral significance that can be drawn based on the Qur'anic expression regarding this basic human nature, according to Sahl at-Tusturī, is to uphold the true khair, which is to fulfill three things: not to depend on fellow creatures, feel the need before God, and carry out His commandments. ${ }^{50}$

On the principle of not hurting (creature), it is implicit in the explanation in the QS section. al-Qașaṣ (28) verse 76.

\footnotetext{
${ }^{47}$ Ibid., 147-148

${ }^{48}$ Ibid., 273

${ }^{49}$ Ibid., 325

50 Ibid.
} 


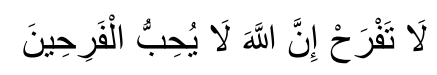

It means: "Do not be too proud; surely Allah does not like people who are too proud of themselves."

According to Sahl at-Tusturī, anyone who is happy without someone being pleased will cause grief for him. It is not called a believer when he is happy without expecting to meet Allah.

Sahl at-Tusturī cites a narration narrated by al-A'masy who said that: "We saw janāzah (people who died), but we do not see anyone who believes in grieving the death of that person".

The principle of repent ance and implicit rights are contained in the explanation in QS. Âli Imrān (3) verse 92.

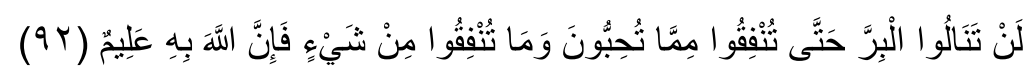

Meaning: You will not get virtue, before you invest some of the treasure that you love. And whatever you want, about that, truly, God knows. The purpose of this verse according to Sahl at-Tusturi is is that we will not arrive at piety until we are able to ignite our passions by spending part of what we love. Infaq is also not only because of lust, but also only expects the pleasure of Allah.

In the explanation of this verse Sahl at-Tusturī also quotes saga;

That the Prophet 'Īsā As. one day walking and meeting with three groups of people. The first group looks thin and changes color. Then the Prophet 'İsā As. ask: "What happened to you?", they answered: "Fear our Creator and remember the torments that will befall us for our sinful conduct", so the Prophet said 'Assa: -His". Then the Prophet 'Īsā As. walked again and met the second group, they looked very thin. Then the Prophet 'İsā As. asking: "What happened to you?", They answered: "A deep longing for our Lord", then said the Prophet .: āsā As: "The right of Allah to give you what you expect". Then the Prophet 'Īsā As. walked again and met the third group who looked very thin and pale in the face. Then the Prophet 'I $\bar{s}$ as As. asking: "What happened to you?." They answered: "Love", then said the Prophet 'āsā As .:" You are a category of people who are close to Allah. Whoever loves Allah, then he is close to Him, because people who love something, he rushed to him. ${ }^{51}$

Based on the saga above, Sahl at-Tusturi said that there are three levels. First; is the level of those who repent; second, is the level of those who yearn; and third, is the level of people who love. ${ }^{52}$

In explaining Q.S. Șād (38) verse 32.

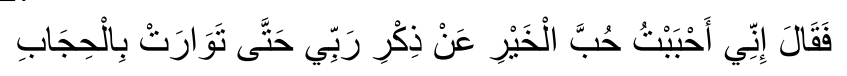

\footnotetext{
${ }^{51}$ Ibid., 125

${ }^{52}$ Ibid.
}

Teosofia: Indonesian Journal of Islamic Mysticism, Volume 7, Number 1, 2019 
Meaning: So, he said: "Surely I like all that is good (horse), which keeps me busy from remembering my Lord's (power), until the sun sets."

Sahl at-Tusturi addresses that love is negligent from performing the 'Așar prayer and its limits. ${ }^{53}$

And in the explanation of Q.S. al-'Ādiyāt (100) verse 8.

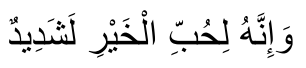

Meaning: and in fact his love for property is really excessive.

The meaning of $h\} u b b$ al-khair in the above verse is, according to Sahl at-Tusturi it can be classified into three types of actions: loving oneself (nafs), loving the world, and loving desires $($ haw $\bar{a}$ ). These three things are named khair because through the "treasure" the owners can get to know each other.

In order for khair to have a positive meaning, then the real khair according to Sahl atTusturī, which is a khair that fulfills three things: does not depend on fellow beings, feels the need before God, and carries out His commands. ${ }^{54}$

Explanation at-Tusturī in the three verses above shows the practice of hubb on the principle of not hurting (creatures), avoiding immorality, repentance and fulfilling rights, such as how the above saga trying to infect all that they can do, and reject everything that can bring them far from Allah.

Based on an explanation of the practice based on the seven principles above shows that all the ideologies and teachings of Sufism at-Tusturi are placed including the teachings and understandings of at-Tusturī about hubb in terms of commitment and consistently practicing Allah's commands and avoiding His prohibitions both in the form of words and deeds .

The gift of love is a help from Allah to His servants, therefore at-Tusturi sees that $h\} u b b$ is not the result of "charity and kasb but is a gift and grace and abundance from God to His servants without waiting and asking. ${ }^{55}$ The togetherness between muhib and mahbūb is felt when the muhib always considers it important to mention his (dhikr) maḥbūb with his mouth and heart. ${ }^{56}$ The sinking of muhib (lover) in referring to his mahbu b (lover) changes the word that is repeated verbally to the presence of a heart that forgets $d z \bar{a} k i r$ in itself and feels comfortable in the presence with his Lord, then he dissolves $(f a n \bar{a})$ in eternity $(b a q \bar{a})$ together -His. This situation is the most grand and high position, this is in line with the phrase "his soul with dhikr and his life dhikr with people who dhikr, and the lives of people who dhikr with madzkur."57

53 Ibid., 231

${ }^{54}$ Ibid., 325.

55 Ibid., 67.

${ }^{56}$ Ibid., 118, 159, 166, 142.

${ }^{57}$ Ibid., 203. 


\section{Conclusion}

Abū Muhammad Sahl ibn 'Abdullāh ibn Yūnus ibn Ī āsā ibn' Abdullāh ibn Rafī 'at-Tusturī who is well known as at-Tuturī, is a figure of a Sufi scholar as well as a mufasir al-Qurān. Zuhd, the nature of wara' science and karomah recognized by the great scholars afterwards. Many of the concepts of Sufism and isyāri interpretation we can learn from it. One of them in relation to this research is the concept of $h\} u b b$. In the view of at-Tusturī, hubb is a state of heart that feels majesty, glory and presence and calm with Allah. Hubb is a great gift, unsolicited and not awaited nor can it be forced. Hubb is present with the dhikr which dissolves (fana) in the baq $\bar{a}$. The fan $\bar{a}$ is the person whose mahabbah is not unity or unity but togetherness or presence (ma'iyyah wa al-hudūr). The key is ma'rifat, because with it someone begins to enter to love Him. The practice is to apply love to Allah and the Prophet, zuhud to the world, to follow the book and the sunnah, and to fear impulsive impulses that encourage stumbling in evilness.

\section{Bibliography}

al-Baihaqī, Abū Bakr. Syu'b al-Īmān, Juz. II, Riyad: Maktabah ar-Rusy li an-Nasyr wa atTauzī'. Cet. I, 1423 H./2003 M.

al-Baq̄î, Muhammad Fu'ād Abd. Mu'jām al-Mufahrās lī Alfāz al-Qurān. Kairo: Dār al-Kutub Mishriyyah, 2004.

al-Gazālī, Abū Ḥāmīd Muḥammad bin Muḥammad. Ihyyā' 'Ulūm ad-Dīn, Juz IV. Beirut: Dār al-Ma'rifah, t.th.

Al-Ghazali, Imam. Ajaran Bahasa Imam Al-Ghazali, Terj. Yudhi AW. Yogyakarta: Cakrawala, 2011. , Samudera Ma'rifat, Terj. Tim Creative Kauka. Yogyakarta: 2008.

al-Manāwī, Zain ad-Dīn Muhammad 'Abd ar-Ra'ūf. al-Kawākib ad-Durriyyah fì Tarājim asSādat aṣ-Ṣufiyyah. Juz. I. Beirūt: Dār Șadir, 2004.

'Ațiyyah, Abū Ṭālib al-Makkī Muḥammad bin 'Ālī bin. Qūt al-Qulūb fì Mu'amālat al-Maḥbūb wa Wașf Ṭarīq al-Murìd ila Maqām at-Tauḥìd, Juz II. Kairo: Maktabah Dār at-Turāis, 1422 H./2001 M.

at-Tusturī, Muḥammad Sahl bin 'Abdullāh. Tafsīr al-Qurān al-Aẓ̄m . Kairo: Dār al-Ḥaram li atTurās, Cet I, 2004.

aż-Żahab̄̄, Muhammad Husain. at-Tafsīr wa al-Mufassirūn, vol. II. Mesir: Dār al-Kutub alHadīìsah, 1961.

Böwering, Gerhard. The Mystical Vision of Existence in Classical Islam; The Qur'änic Hermeneutics of Sufi at-Tustarī (d. 283/896). Berlin, New York: de Gruyter, 1979.

Teosofia: Indonesian Journal of Islamic Mysticism, Volume 7, Number 1, 2019 
Khallikān, Abū al-'Abbās Syams ad-Dīn Aḥmad bin As'ad bin Muḥammad bin Abī Bakr bin. Wafiyāt al-A 'yān wa Anbā'u Anbā'i az-Zamān, Jilid. II. Beirūt: Dār Șadir, 1397 H./ 1977 M.

Maḥmūd, Man̄̄’ Abd al-Ḥalīm. Manāhij al-Mufassirīn. Kairo: Dār al-Kutub al-Miṣrī, 2000.

Maḥmūd, 'Abd al-Ḥalīm. al- 'Ārif billāh Sahl bin 'Abdullāh at-Tusturī Hayātuhu wa Ārāuhu. Kairo: Dār al-Ma’ārif, 1994.

Maslow, Abraham H. Motivasi dan Kepribadian-2. Jakarta: Midas Surya Grafindo, 1993.

Masyhudi, In'amuzzahidin. Dari Waliyullah Menjadi Wali Gila. Semarang: Syifa Press, 2007.

Munawir, Ahmad Warson. Kamus al-Munawwir Arab-Indonesia Terlengkap. Surabaya: Pustaka Progressif, 1997.

Rahman, Fazlur. Tema Pokok Al-Qur'ān, trans. Anas Mahyudin. Bandung, Pustaka, cetakan kedua, 1996.

Shihab. Muhammad Quraish, Tafsir al-Misbah: Pesan, Kesan, dan Keserasian al-Qur'an, Vol. II. Jakarta: Lentera Hati, 2005.

Sobur, Alex, Psikologi Umum. Bandung: CV. Pustaka Setia sobur,2003.

Tohir, Moenir Nahrowi. Menjelajahi Eksistensi Tasawuf. Jakarta: As-salam Sejahtera, 2012.

Wilcox, Lynn. Psikologi Kepribadian. Jogjakarta: IRCiSoD, 2013. 